\title{
Elevated expression of Dickkopf-1 increases the sensitivity of human glioma cell line $\mathrm{SHG}_{44}$ to BCNU
}

\author{
Youxin Zhou $^{\dagger}$, Wenshuai Li ${ }^{\dagger}$, Qinian Xu, Yulun Huang ${ }^{*}$
}

\begin{abstract}
Background: Studies have shown that Dickkopf-1 (DKK-1) is involved in tumorigenesis. Recently, we found that 9 out of 12 human glioma cell lines had high level of DKK-1 protein while the other 3 had very low or nondetectable level of DKK-1. The aim of this study is to further examine the function of DKK-1 in glioma cells.

Materials and methods: The glioma cell line $\mathrm{SHG}_{44}$ was obtained from a patient with grade II-III astrocytoma. $\mathrm{SHG}_{44}$ cells were transfected with a human DKK-1 gene. Transfection of the empty vector pCDNA3.1 was used as negative control. Sensitivity to BCNU was measured by Annexin- $V$ staining. Expression of bax, bcl-2 and caspase-3 of three groups was determined by immunohistochemistry.

Results: The tranfection was confirmed by PCR, RT-PCR and Western blot. More apoptotic cell death was observed in the DKK-1 transfected cells, comparing to the non-transfected cells, or cells with empty vector. The expression of bax and caspase-3 of the $\mathrm{SHG}_{44}$-DDK-1 increased, whereas the expression of bcl-2 decreased

Conclusion: Our results indicated that DKK-1 has a pro-apoptotic function of in glioma.
\end{abstract}

\section{Introduction}

Dickkopf-1(DKK-1) gene was first discovered in 1998 as a head formation inducer and an antagonist of Wnt signaling pathway [1]. In normal tissues of human body, DKK-1 mRNA was highly expressed in placenta and at a very low level in prostate only $[2,3]$. Recent studies have revealed the involvement of DKK-1 protein in tumorigenesis. Its exact role in tumorigenesis, however, still remains unclear. Several studies reported that the expression level of DKK-1 in different tumors was different and its biological functions were different as well [4-8]. DDK-1 expression was confirmed in several cancer cell lines derived from breast and other common cancers. DDK-1 protein secretion was documented in breast, prostate and lung cancers, but was negligible in melanoma [9]. The DKK-1 concentration was significantly higher in the serum of lung cancer patients than in that of other malignant tumor patients or healthy people. The DKK-1 concentration is significantly lower in serum of patients with gastric cancer, colorectal cancer, ovarian cancer, and cervical

\footnotetext{
* Correspondence: johnhyl@163.com

† Contributed equally

Department of Neurosurgery, the First Affiliated Hospital of Soochow University, Suzhou 215006, China
}

adenocarcinoma compared with healthy people [10]. DKK-1 is a candidate gene for tumor suppressor in glioma and considered as a serologic and prognostic biomarker.In our recent study of 12 human glioma cell lines, we found that the supernatant fluid and lysate of 9 cell lines had high level of DKK-1 protein and the other 3 had very low level or non-detectable DKK-1 protein (Zhou et al, unpublished data). The high level of DKK-1 protein in most glioma cell lines suggested that DKK-1 may play an important role in glioma and attracted our intention to further study this DKK-1's function in glioma.

In this study we constructed a eukaryotic expression vector of human DKK-1(pcDNA3.1-DKK-1) and stably transfected the vector into the glioma cell line $\mathrm{SHG}_{44}$, which had no expression of DKK-1 under normal growth condition. We found that elevated expression of DKK-1 increased the sensitivity of $\mathrm{SHG}_{44}$ cells to the anti-cancer drug $\mathrm{BCNU}$ in vitro.

\section{Materials and methods Construction of expression vector}

The 816-base pair human DKK-1 cDNA was amplified from the RNA of human placenta tissue using reverse 
transcription polymerase chain reaction (RT-PCR). The sequence of sense primer was 5'-CTAGCTAGCACATGATGGCT CTGG-3' (NHe I enzyme digestion site was indicated as underline) and antisense primer was 5'GGAATTCGTGTCTCTGACAAGTGTG-3' (EcoR I enzyme digestion site was indicated as underline). The PCR reaction $(10 \mu \mathrm{l})$ contained $1 \mu \mathrm{l}$ cDNA, $1 \mu \mathrm{l} 10 \times$ buffer $\left(\mathrm{MgCl}_{2}\right), 0.4 \mathrm{mM}$ dNTPs, 1 umol primer, $1 \mathrm{U}$ TaqDNA Polymerase. After denaturation at $95^{\circ} \mathrm{C}$ for 5 min, PCR was performed for 35 cycles $\left(30 \mathrm{~s}\right.$ at $95^{\circ} \mathrm{C}, 30$ $\mathrm{s}$ at $50^{\circ} \mathrm{C}$ and $30 \mathrm{~s}$ at $72^{\circ} \mathrm{C}$ ) and extended at $72^{\circ} \mathrm{C}$ for 5 min. The linear NHeI-EcoRI fragment containing the DKK-1 cDNA was subcloned into pcDNA3.1 (Invitrogen Company), which yielded pcDNA3.1-DKK-1 by T4 ligase (TaKaRa Company). The insertion of DDK-1 in pcDNA3.1 was confirmed by PCR, restriction enzyme digestion analysis (NHeI and EcoRI) and DNA sequencing.

\section{Cell culture}

The human glioma cell line $\mathrm{SHG}_{44}$ was established by our lab in 1984 and has been widely used in China. It was originally obtained from a patient with grade II-III astrocytoma (according to World Health Organization). Cells were cultured in RPMI1640 medium (Giboc Company) supplemented with $10 \%$ fetal bovine serum, 100 $\mathrm{IU} / \mathrm{ml}$ penicillin and $100 \mu \mathrm{g} / \mathrm{ml}$ streptomycin. Cells were cultured at $37^{\circ} \mathrm{C}$ in a humidified atmosphere containing $5 \%$ carbon dioxide. The culture medium was changed every $48 \mathrm{~h}$.

\section{Determination of the optimal concentration of G418}

G418 is an aminoglycoside and is commonly used as a selective agent for the bacterial neo $\mathrm{r} / \mathrm{kan} \mathrm{r}$ genes. The optimal concentration of G418 for selection of resistance was determined by the following procedure. $\mathrm{SHG}_{44}$ cells were plated at the same concentration of $5 \times 10^{4} /$ well, in 24-well plates containing $2 \mathrm{ml}$ culture medium per well. G418 (sigma Company) was added to wells at 10 different concentrations $(75,100,150,200,300,400,500,600,700$, $800 \mu \mathrm{g} / \mathrm{ml})$. The culture media were changed once per 48 h. The lowest G418 concentration, in which all cell died after 12-14 days culture, was chosen as the optimal concentration for resistance selection.

\section{Transfection of $\mathrm{SHG}_{44}$ cells with pcDNA3.1-DKK-1}

For stable transfection of the DKK-1 gene, $\mathrm{SHG}_{44}$ cells $\left(1 \times 10^{6}\right)$ were plated in 6-well plates 24 h before transfection. Lipofectamine 2000 (Invitrogen Company) was used to mediate transfection using $5.0 \mu \mathrm{g}$ of pcDNA3.1DKK-1 vector or $5.0 \mu \mathrm{g}$ of empty pcDNA3.1 vector as a control according to the manufacture's protocol. After $48 \mathrm{~h}$ transfection, the cells were selected in media supplemented with G418 $(150 \mu \mathrm{g} / \mathrm{ml})$. The medium was changed once per $48 \mathrm{~h}$. Non-transfected $\mathrm{SHG}_{44}$ cells died within two weeks. G418-resistant cells were selected and named as $\mathrm{SHG}_{44}$-DKK-1. Cells with empty vector of pcDNA3.1 were named as $\mathrm{SHG}_{44}-\mathrm{EV}$.

\section{PCR confirmation of DKK-1 in $\mathrm{SHG}_{44}$ cells}

DNA from cells of normal $\mathrm{SHG}_{44}, \mathrm{SHG}_{44}-\mathrm{EV}, \mathrm{SHG}_{44}-$ DKK-1 was isolated using a DNA extraction kit (Puregenetm DNA isolation kit, Gentra systems). A portion of the DKK-1 gene was used to design the primers. The upstream primer sequence was 5'-TCACGCTATGTGCTGCCCCG-3' and downstream 5'-TGAGGCACAGTCTGATGACCGGA-3'. The expected product was $223 \mathrm{bp}$. PCR reaction system $(50 \mu \mathrm{l})$ was: $3 \mu \mathrm{l}$

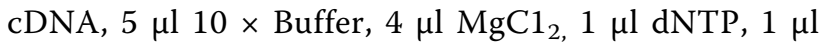
primer, $0.3 \mu \mathrm{l}$ TaqDNA Polymerase. PCR reaction condition was: an initial denaturation step of $94^{\circ} \mathrm{C}$ for 7 min, followed by 30 cycles of a three-step program of $94^{\circ} \mathrm{C}$ for $30 \mathrm{~s}, 56^{\circ} \mathrm{C}$ for $30 \mathrm{~s}, 72^{\circ} \mathrm{C}$ for $45 \mathrm{~s}$, and a final extension step of $72^{\circ} \mathrm{C}$ for $7 \mathrm{~min}$. All the products were electrophoresed on the agarose gel.

\section{RT-PCR of DKK-1 mRNA}

Analysis of the DKK-1 mRNA expression of the three groups of cells (normal $\mathrm{SHG}_{44}, \mathrm{SHG}_{44}$-EV and $\mathrm{SHG}_{44}$ DKK-1) was performed by RT-PCR. Total RNA from cell lines was isolated using Trizol (Invitrogen Company). The purity and concentration of total RNA were detected by UV chromatogram analyzer (Backma Company). The concentration of RNA was adjusted to $1 \mu \mathrm{g} / \mu \mathrm{l}$. $\beta$-actin was used as an internal control to ensure RNA quality and loading accuracy. Primer sequences were 5'-AGCGAGCATCCCCCA AAGTT-3' (upstream) and 5'GGGCACGAA GGCTCATCATT-3' (downstream). The predicted product size is $285 \mathrm{bp}$. The primers for DKK-1 were the same mentioned above. The PCR condition for DKK- 1 and $\beta$-actin was the same as described above.

\section{Western blot analysis}

The total protein of the three groups of cells (normal $\mathrm{SHG}_{44}, \mathrm{SHG}_{44}-\mathrm{EV}, \mathrm{SHG}_{44}$-DKK-1) was extracted directly in the lysis buffer and the concentration of total protein was quantified by UV chromatogram analyzer. $50 \mu \mathrm{g}$ protein was separated using $12 \%$ sodium dodecyl sulfate- polyacrylamide gel (SDS-PAGE). After electrophoresis, proteins were transferred from gel to zapon fibrous membrane and the membrane was blocked by 5\% non-fat milk. Monoclonal mouse anti-human DKK-1 antibody (R \& D Company) (1:1000 dilution) was probed. For loading control, membranes were striped and reprobed with mouse anti-human $\beta$-actin antibody (R\&D Company)(1:1000 dilution). Horseradish peroxidase (HRP)-conjugated goat-anti-mouse antibody (Coulter Immunotech Company) were added. Protein bands 
were visualized using the enhanced chemiluminescence system (Millipore Company).

\section{Apoptosis analysis}

Normal $\mathrm{SHG}_{44}, \mathrm{SHG}_{44 .}-\mathrm{EV}$ and $\mathrm{SHG}_{44}-\mathrm{DKK}-1$ cells were incubated in 6-well plates by $1 \times 10^{6}$ cells/well) in medium with or without $50 \mu \mathrm{M}$ BCNU (Medical Isotopes Company) for 24 hours. Apoptosis was detected using the Annexin V-FITC Apoptosis Detection Kit (Jingmei Company). Briefly, cells were harvested and then resuspended in $1 \mathrm{ml}$ of buffer followed by addition of $5 \mu \mathrm{l}$ Annexin V and $10 \mu \mathrm{l} \mathrm{PI}$. Cells were incubated in the dark at room temperature for $15 \mathrm{~min}$. Cell death was determined using a flow cytometer (Backman Company). Data were obtained and analyzed by CellQuest software (Largo Company).

\section{Immunohistochemical analysis for bax, bcl-2 and caspase-3}

Normal $\mathrm{SHG}_{44}, \mathrm{SHG}_{44 .}-\mathrm{EV}$ and $\mathrm{SHG}_{44}-\mathrm{DKK}-1$ cells were incubated in 6 -well plates by $1 \times 10^{6}$ cells/well in medium with or without $50 \mu \mathrm{M}$ BCNU (Medical Isotopes Company) for 24 hours. Cells were washed in 0.05 $\mathrm{M}$ phosphate-buffered saline (PBS) (pH. 7.4) for 15 minutes then fixed in $4 \%$ paraformaldehyde for 20 minutes. Streptavidin/biotin-peroxidase (SP) method was used for immunohistochemical staining. The primary antibodies, namely antibodies against bax, bcl-2 and caspase- 3 (Wuhan Boster Biological Technology, China), were diluted at 1:100. PBS was used as control. Labeled cells was photographed and the integrated optical density (IOD) was measured using Image pro plus 5.02 (Media Cybernetics, USA).

\section{Statistical analyses}

The difference between controls and treated groups were analyzed by $\chi^{2}$-test. Differences were considered significant if $\mathrm{P}<0.05$. Statistics was performed with SPSS 13.0 software for Windows (LEAD Technologies, Chicago, IL, USA).

\section{Results}

\section{DKK-1 CDNA amplification and identification of} expression vector

We first designed the primers and amplified the $816 \mathrm{bp}$ DKK-1 gene from human placenta tissue. The PCR product was collected and purified. The purified DKK-1 fragment and pcDNA3.1 vector were digested by NHe I and EcoR I, followed by ligation with T4 ligase at $16^{\circ} \mathrm{C}$ for overnight. The ligated plasmid was transformed into DH5 $\alpha$ strain of E. coli. Single colonies were selected and PCR amplification confirmed a single band of 816 bp. The plasmids were isolated from $\mathrm{DH} 5 \alpha$ and digested by NHe I and EcoR I. DNA gel showed two bands, one corresponding to the $816 \mathrm{bp}$ fragment and the second one corresponding to the vector pcDNA3.1. DNA Sequencing showed that the $816 \mathrm{bp}$ fragment matched with the DNA sequence of DKK-1 gene.

\section{Cell morphology and $\mathrm{SHG}_{44}$-DKK-1 screening}

Normal $\mathrm{SHG}_{44}$ cells were usually elongated and football shaped (Fig.1a). They died within two weeks when cultured in the presence of $150 \mu \mathrm{g} / \mathrm{ml} \mathrm{G418} \mathrm{(Fig.1b).} \mathrm{Cells}$ transfected with pcDNA3.1-DKK-1 were resistant to G418 and were screened under G418 for about three weeks and named as $\mathrm{SHG}_{44}$-DKK-1. The $\mathrm{SHG}_{44}$-DKK-1 cells appeared similar to the non-transfected cells and sometimes formed clusters (Fig.1c, d).

\section{PCR analysis of DKK-1 in SHG $_{44}$ cells}

DNA was extracted from cells of normal $\mathrm{SHG}_{44}, \mathrm{SHG}_{44^{-}}$ EV and $\mathrm{SHG}_{44}-\mathrm{DKK}-1$. The extracted DNA was amplified by PCR using the primer pair described above. As expected, a 223bp fragment was observed in $\mathrm{SHG}_{44}$

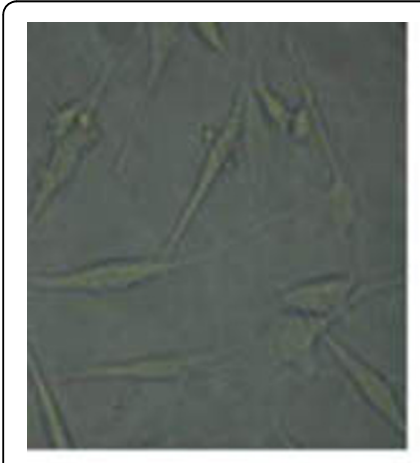

$1 \mathrm{a}$

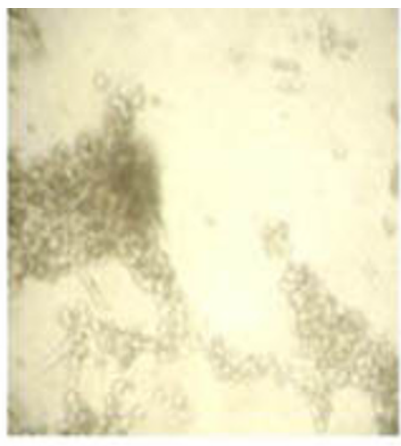

$1 b$

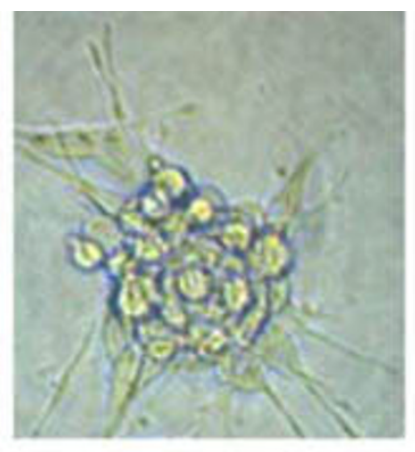

$1 \mathrm{c}$

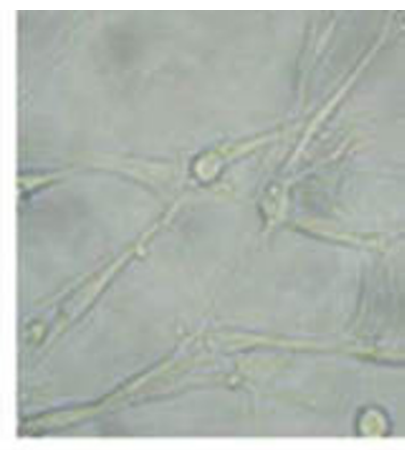

$1 \mathrm{~d}$

Figure 1 Microscopic images of different groups cells in selection. Normal $\mathrm{SHG}_{44}(1 \mathrm{a})$, normal $\mathrm{SHG}_{44}$ cells cultured in the presence of G418 for two weeks (1b); and SHG 44 -DKK-1 cells cultured in the presence of G418 for three weeks (1c, 1d). 
-DKK-1cells, but not in normal $\mathrm{SHG}_{44}$, or $\mathrm{SHG}_{44}$-EV cells (Fig.2). This result further confirmed the specific transfection of DKK-1 gene into the $\mathrm{SHG}_{44}$ cells.

DKK-1 mRNA expression in $\mathrm{SHG}_{44}$ cells

RNA extracted from normal $\mathrm{SHG}_{44}, \mathrm{SHG}_{44}-\mathrm{EV}$ and $\mathrm{SHG}_{44}$-DDK-1 cells was amplified by RT-PCR and subsequently analyzed by DNA gel. A prominent $223 \mathrm{bp}$ band was detected from $\mathrm{SHG}_{44}$-DKK-1 cells, but nondetectable from $\mathrm{SHG}_{44}$-EV cells or normal $\mathrm{SHG}_{44}$ cells (Fig.3).

\section{DKK-1 protein expression in SHG $_{44}$ cells}

The total protein exacted from normal $\mathrm{SHG}_{44}, \mathrm{SHG}_{44}-$ EV and $\mathrm{SHG}_{44}$-DDK-1 cells was separated using $12 \%$ SDS-PAGE and was subsequently analyzed by Western blot. A 35KD band, which corresponds to the size of DKK-1 protein was observed in $\mathrm{SHG}_{44}$-DKK-1 cells, but not in $\mathrm{SHG}_{44}-\mathrm{EV}$ or normal $\mathrm{SHG}_{44}$ cells (Fig.4).

\section{BCNU induced apoptosis}

$\mathrm{BCNU}$ is an anti-cancer drug and an inducer of apoptotic cell death. We used BCNU to further assess the role of DKK-1 in $\mathrm{SHG}_{44}$ cells. Apoptosis was observed in all three groups of cells: normal $\mathrm{SHG}_{44}, \mathrm{SHG}_{44}-\mathrm{EV}$ and $\mathrm{SHG}_{44}-\mathrm{DDK}-1$. The average apoptosis ratio of normal $\mathrm{SHG}_{44}, \mathrm{SHG}_{44}$-EV cells and $\mathrm{SHG}_{44}-\mathrm{DKK}-1$, was $2.5 \pm$ $0.2 \%, 1.8 \pm 0.2 \%, 8.4 \pm 0.3 \%$, respectively(Fig.5). The apoptosis ratio of $\mathrm{SHG}_{44}-\mathrm{DKK}-1$ cells was significantly $(\mathrm{P}<0.05)$ higher than that of normal $\mathrm{SHG}_{44}$ or $\mathrm{SHG}_{44^{-}}$ EVcells. Minimal apoptosis was observed in all three groups of cells in the absence of BCNU.

\section{Immunohistochemistry analysis}

Images of bax, caspase- 3 and bcl-2 staining are shown in Figure 6. The positive reaction located in cytosol was stained in brown. The color of the stain is positively

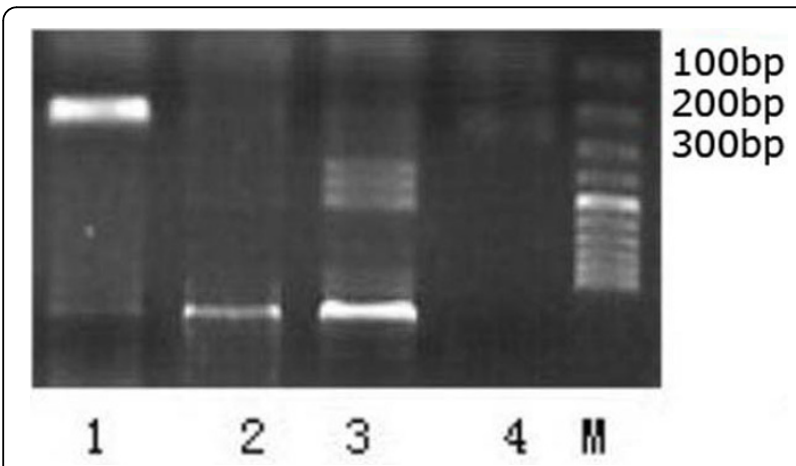

Figure 2 PCR amplification of DKK-1 SHG 44 -DKK-1 cells was lane $1, \mathrm{SHG}_{44}-\mathrm{EV}$ was lane 2 , normal $\mathrm{SHG}_{44}$ cells was lane 3 and control (culture medium only) was lane 4. $M$ was the marker for standard DNA molecular mass.

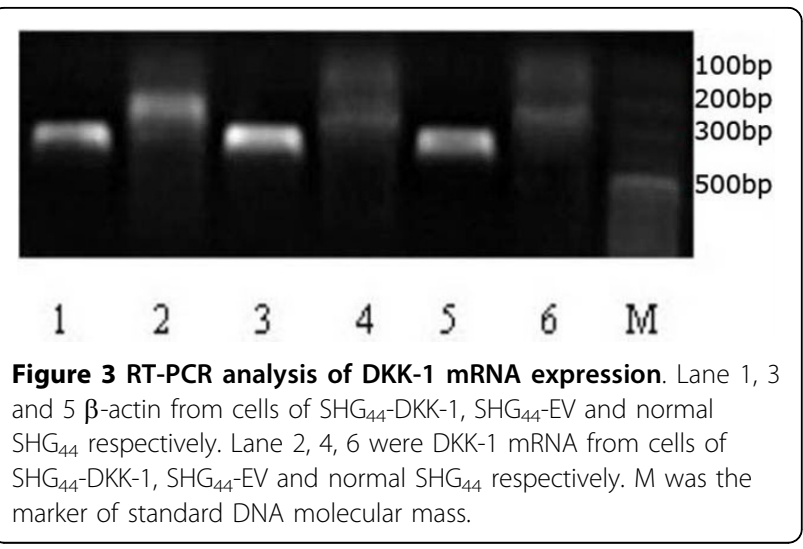

correlated to the protein expression. The IOD of each group revealed that in the $\mathrm{SHG}_{44}$-DDK-1 the expression of bax and caspase- 3 increased, whereas the expression of bcl-2 decreased (Table 1).

\section{Discussion}

The family of DKK genes is a small, but conservative gene family, which is composed of DKK-1, DKK-2, DKK-3, DKK-4 and DKKL-1 (also called Soggy), a DKK3 related gene. DKK proteins possess different structure and function, but many of them play important roles in various human diseases [2]. DKK-1 is the most well-studied gene in the DKK gene family. It is mapped to chromosome 10q11.2 [11] and encodes a secretory glucoprotein, which contains 266 amino acids with a molecular weight of $35 \mathrm{KD}$. The glucoprotein contains a $\mathrm{N}$-terminal signal peptide of 31 amino acids, two conserved cysteine-rich domains and a C-terminus with glycosylation function. DKK-1 acts as a wnt antagonist by forming a complex with the transmembrane proteins Kremen 1 and $2(\mathrm{Krm} 1 / 2)$ and low- density-lipoprotein $5 / 6$ (LRP5/6). The complex is then removed through endocytosis, resulting in the removal of LRP5/6 from the cell surface $[12,13]$ Recent studies revealed that DKK-1 is not only an antagonist of classic Wnt/ $\beta$-cantenin signaling pathway but also a direct regulator of transcription of its target genes [14].

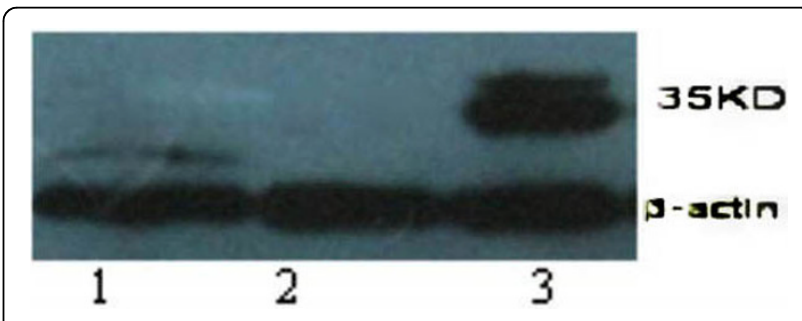

Figure 4 Western blot analysis of DKK-1 protein. It showing DKK-1 protein from cells of normal SHG 44 (lane 1), $\mathrm{SHG}_{44}$-EV (lane 2) and $\mathrm{SHG}_{44}$-DKK-1 (Lane 3). $\beta$-actin was used as loading control. 

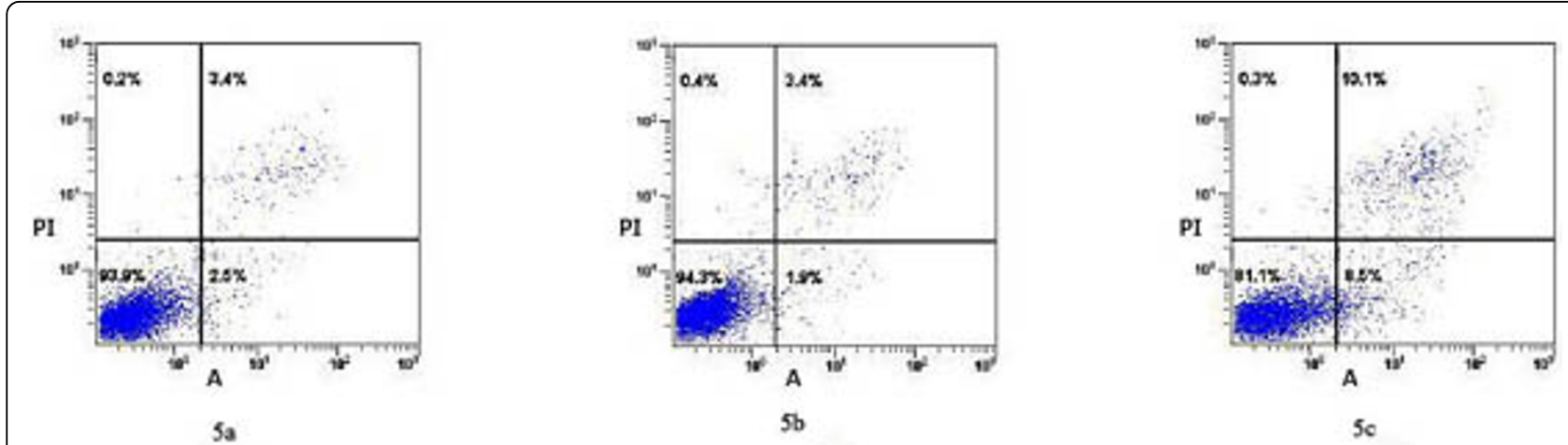

Figure 5 Apoptosis ratio was detected by flow cytometry analysis. Representative image of flow cytometry analysis of BCNU treated cells, showing the apoptosis ratio (right lower-quadrant) of normal $\mathrm{SHG}_{44}$ (a), SHG $\mathrm{SH}_{4}-\mathrm{EV}$ (b) and $\mathrm{SHG}_{44}$-DKK-1 (c) cells.

The function of DKK-1 in tumor progression has been shown to be complicated and even controversial. A number of studies showed that DKK-1 induces apoptosis and inhibits tumor growth [15-17] DKK-1 expression in primary medulloblastoma cells is significantly down- regulated relative to normal cerebellum and transfection of a DKK-1 gene construct into D283 cell line suppresses medulloblastoma tumor growth [18]. In addition, adenoviral vector-mediated expression of DKK-1 in medulloblastoma cells significantly increases the
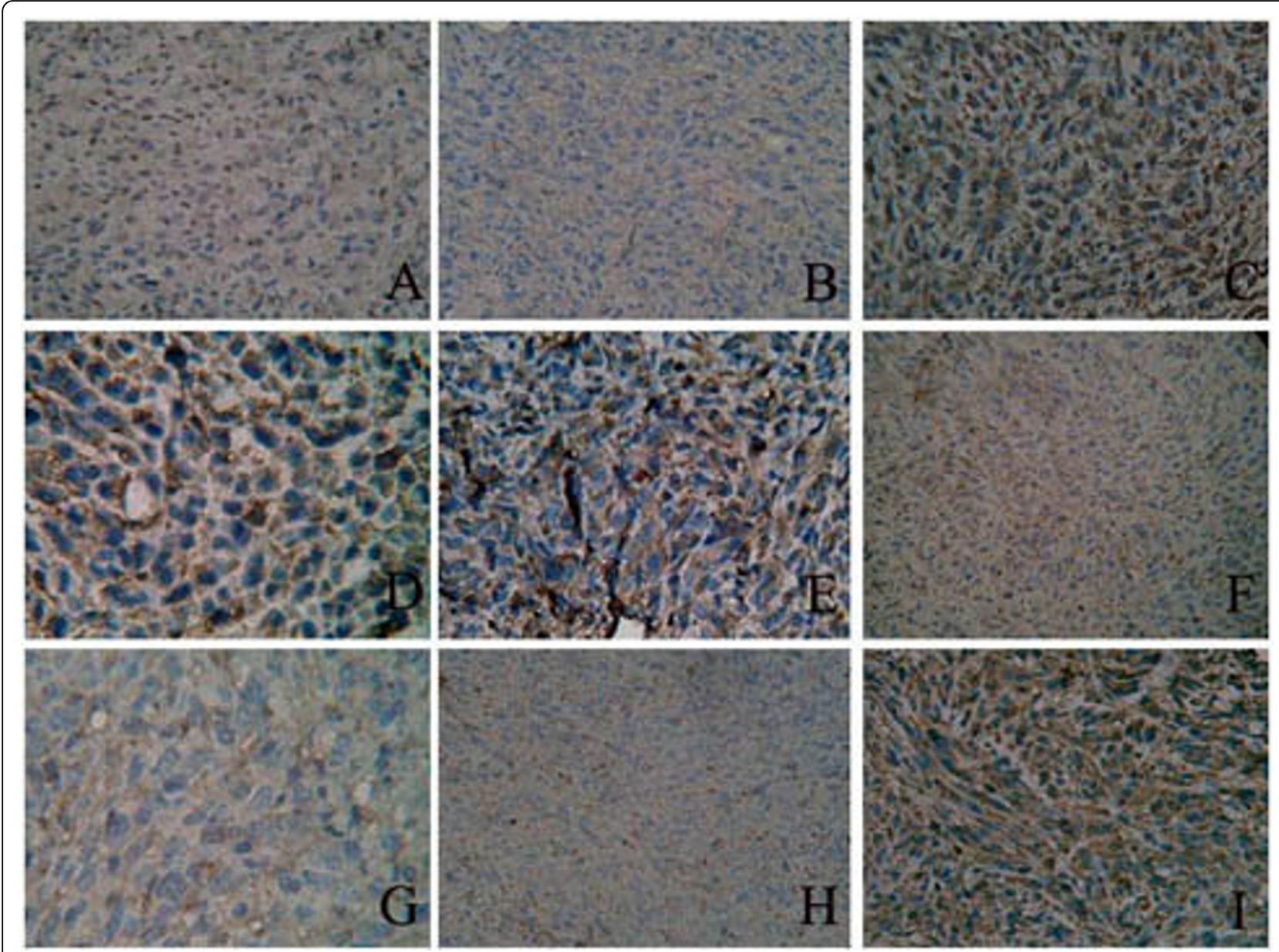

Figure 6 Bax, bcl-2 and caspase-3 protein expression inthree groups cell (×400). (A) Bax normal SHG $44 ;(B) B a x ~ S H G 44-E V ;(C) B a x ~ S H G 44-D K K-$ 1;(D) BCl-2 normal SHG 44 (E)BCl-2 SHG 44 EV; (F)BCl-2 SHG 44 -DKK-1; (G)Caspase-3 normal SHG 44; (H)Caspase-3 SHG 44 -EV; (I)Caspase-3 SHG 44 -DKK-1. 
Table 1 Bax, bcl-2 and caspase-3 expression (in IOD) in normal $\mathbf{S H G}_{\mathbf{4 4}}, \mathrm{SHG}_{\mathbf{4 4}}-\mathrm{EV}$ and $\mathrm{SHG}_{\mathbf{4 4}}-\mathrm{DKK}-1$ cells

\begin{tabular}{lccc}
\hline & $\begin{array}{c}\text { Bax protein } \\
\text { expression }\end{array}$ & $\begin{array}{c}\text { Bcl-2 protein } \\
\text { express }\end{array}$ & $\begin{array}{c}\text { Caspase-3 protein } \\
\text { express }\end{array}$ \\
\cline { 2 - 4 } & $\mathbf{n}=\mathbf{6}$ IOD & $\mathbf{n}=\mathbf{6}$ IOD & $\mathbf{n}=\mathbf{6}$ IOD \\
\hline normal SHG 44 & $2323 \pm 305$ & $5046 \pm 521$ & $1845 \pm 126$ \\
$\mathrm{SHG}_{44}-\mathrm{EV}$ & $2623 \pm 420$ & $6417 \pm 462$ & $1920 \pm 231$ \\
$\mathrm{SHG}_{44}-\mathrm{DKK}-1$ & $4567 \pm 598^{*}$ & $2900 \pm 302^{*}$ & $3944 \pm 511^{*}$ \\
\hline
\end{tabular}

${ }^{*} \mathrm{P}<0.05$.

apoptosis rate. DKK-1, however, is also reported to be overexpressed in tissues and serum of lung cancers and esophageal squamous cell carcinoma, suggesting that DKK-1 may act as pro-oncogene [19]. Differential gene expression analysis showed that the resistance of the CAL27 cell line to cisplatin, an anti-cancer chemotherapy drug, is associated with the expression level of DKK-1 [20]. The expression level of DKK-1, an inhibitor of canonical WNT signaling, was decreased in Cal27cis, a sub-cell line of Cal27, and was obtained by treating Cal27 with increasing concentrations of cisplatin. Overexpression of DKK-1 in both Cal27 and Cal27cis resulted in increased sensitivity to cisplatin, suggesting DKK-1 and the WNT signaling pathway as a marker and target for cisplatin chemosensitivity.

In human glioma cells, a previous study showed that transfection of DKK-1into human glioma cell line U87MG causes the cells more sensitive to cisplatin and alkylating agent [15]. Our current study revealed that the expression of bax and caspase- 3 increased, whereas the expression of bcl-2 decreased in the $\mathrm{SHG}_{44}-\mathrm{DDK}-1$ cells, further confirming the pro-apoptosis function of DKK-1. We speculate that the function of DKK-1 may be tissue or cell type specific. Another possibility is that mutations of DKK-1 could be the causes of different functions of DKK-1. A screening of 73 brain tumors, however, revealed that no obvious mutations of DKK-1 were found in these brain tumors [21]. More studies, especially direct comparison of DKK-1 in different cell types at the same condition, are needed in order to better understand the complex functions of DKK-1 in relation to cancer development.

\section{Acknowledgements}

This work was partially supported by major issues Foundation of health department in Jiangsu province ( $K$ 200508). This manuscript has been edited and proofread by Medjaden Bioscience Limited.

\section{Authors' contributions}

$Y Z$ conceived of the study, and participated in its design and coordination and helped to draft the manuscript. WL carried out the molecular genetic studies. QX participated in its design and coordination. YH participated in the conception and the design of the analysis. All authors read and approved the final manuscript

\section{Competing interests}

The authors declare that they have no competing interests.

Received: 1 June 2010 Accepted: 4 October 2010

Published: 4 October 2010

\section{References}

1. Glinka A, Wu W, Delius H, Monaghan AP, Blumenstock C, Niehrs C: Dickkopf-1 is a member of a new family of secreted proteins and functions in head induction. Nature 1998, 391:357-362.

2. Krupnik VE, Sharp JD, Jiang C, Robison K, Chickering TW, Amaravadi L, Brown DE, Guyot D, Mays G, Leiby K, Chang B, Duong T, Goodearl AD, Gearing DP, Sokol SY, McCarthy SA: Functional and structural diversity of the human Dickkopf gene family. Gene 1999, 238:301-313.

3. Yamabuki T, Takano A, Hayama S, Ishikawa N, Kato T, Miyamoto M, Ito T, Ito H, Miyagi Y, Nakayama H, Fujita M, Hosokawa M, Tsuchiya E, Kohno N, Kondo S, Nakamura Y, Daigo Y: Dickkopf-1 as a novel serologic and prognostic biomarker for lung and esophageal carcinomas. Cancer Res 2007, 67:2517-2525.

4. González-Sancho JM, Aguilera O, García JM, Pendás-Franco N, Peña C, Cal S, García de Herreros A, Bonilla F, Muñoz A: The Wnt antagonist DICKKOPF-1 gene is a downstream target of beta- catenin/TCF and is downregulated in human colon cancer. Oncogene 2005, 24:1098-1103.

5. Wirths $O$, Waha A, Weggen $S$, Schirmacher P, Kühne T, Goodyer CG, Albrecht S, Von Schweinitz D, Pietsch T: Overexpression of human DICKKOPF-1, an antagonist of wingless/WNT signaling, in human hepatoblastoma and Wilms'tumor. Lab Invest 2003, 83:429-434.

6. Kuphal S, Lodermeyer S, Bataille F, Schuierer M, Hoang BH, Bosserhoff AK: Expression of DICKKOPF genes is strongly reduced in malignant melanoma. Oncogene 2006, 25:5027-5036.

7. Tian E, Zhan F, Walker R, Rasmussen E, Ma Y, Barlogie B, Shaughnessy JD Jr: The role of the Wnt-signaling antagonist DKK-1 in the development of osteolyic lesions in multiple myeloma. N Engl J Md 203349 : 2483-2494.

8. Patil MA, Chua MS, Pan KH, Lin R, Lih CJ, Cheung ST, Ho C, Li R, Fan ST, Cohen SN, Chen X, So S: An integrated data analysis approach to characterize genes highly expressed in hepatocellular carcinoma. Oncogene 2005, 24:3737-3747.

9. Forget MA, Turcotte S, Beauseigle D, Godin-Ethier J, Pelletier S, Martin J, Tanguay S, Lapointe R: The Wnt pathway regulator DKK1 is preferentially expressed in hormone-resistant breast tumours and in some common cancer types. Br J Cancer 2007, 96:646-53.

10. Sheng SL, Huang G, Yu B, Qin WX: Clinical significance and prognostic value of serum Dickkopf-1 concentrations in patients with lung cancer. Clin Chem 2009, 55:1656-64.

11. Fedi P, Bafico A, Nieto Soria A, Burgess WH, Miki T, Bottaro DP, Kraus MH, Aaronson SA: Isolation and biochemical characterization of the human Dkk-1 homologue, a novel inhibitor of mammalian Wnt signaling. J Biol Chem 1999, 274:19465-19472.

12. Mao B, Wu W, Davidson G, Marhold J, Li M, Mechler BM, Delius H, Hoppe D, Stannek P, Walter C, Glinka A, Niehrs C: Kremen proteins are Dickkopf receptors that regulate $\mathrm{Wnt} /$ beta-catenin signaling. Nature 2002, 417:664-667.

13. Mao B, Wu W, Li Y, Hoppe D, Stannek P, Glinka A, Niehrs C: LDL-receptorrelated protein 6 is a receptor for Dickkopf proteins. Nature 2001, 411:321-325

14. Niida A, Hiroko T, Kasai M, Furukawa Y, Nakamura Y, Suzuki Y, Sugano S, Akiyama T: DKK-1, a negative regulator of Wnt signaling, is a target of the beta-catenin/TCF pathway. Oncogene 2004, 23:8520-8526.

15. Shou J, Ali-Osman F, Multani AS, Pathak S, Fedi P, Srivenugopal KS: Human Dkk-1, a gene encoding a Wht antagonist, responds to DNA damage and its overexpression sensitizes brain tumor cells to apoptosis following alkylation damage of DNA. Oncogene 2002, 21:878-889.

16. Mikheev AM, Mikheeva SA, Liu B, Cohen P, Zarbl H: A functional genomics approach for the identification of putative tumor suppressor genes: Dickkopf-1 as suppressor of HeLa cell transformation. Carcinogenesis 2004, 25:47-59.

17. Peng S, Miao C, Li J, Fan X, Cao Y, Duan E: Dickkopf-1 induced apoptosis in human placental choriocarcinoma is independent of canonical Wnt signaling. Biochem Biophys Res Commun 2006, 350:641-647. 
18. Vibhakar R, Foltz G, Yoon JG, Field L, Lee H, Ryu GY, Pierson J, Davidson B, Madan A: Dickkopf-1 is an epigenetically silenced candidate tumor suppressor gene in medulloblastoma. Neuro Oncol 2007, 9:135-144.

19. Yamabuki T, Takano A, Hayama S, Ishikawa N, Kato T, Miyamoto M, Ito T, Ito H, Miyagi Y, Nakayama H, Fujita M, Hosokawa M, Tsuchiya E, Kohno N, Kondo S, Nakamura Y, Daigo Y: Dikkopf-1 as a novel serologic and prognostic biomarker for lung and esophageal carcinomas. Cancer Res 2007, 67:2517-2525.

20. Gosepath EM, Eckstein N, Hamacher A, Servan K, von Jonquieres G, Lage H, Györffy B, Royer HD, Kassack MU: Acquired cisplatin resistance in the head-neck cancer cell line Cal27 is associated with decreased DKK1 expression and can partially be reversed by overexpression of DKK1. Int J Cancer 2008, 123:2013-2019.

21. Mueller W, Lass U, Wellmann S, Kunitz F, von Deimling A: Mutation analysis of DKK1 and in vivo evidence of predominant p53-independent DKK1 function in gliomas. Acta Neuropathol (Berl) 2005, 109:314-320.

doi:10.1186/1756-9966-29-131

Cite this article as: Zhou et al: Elevated expression of Dickkopf- 1 increases the sensitivity of human glioma cell line $\mathrm{SHG}_{44}$ to $B C N U$. Journal of Experimental \& Clinical Cancer Research 2010 29:131.

\section{Submit your next manuscript to BioMed Central} and take full advantage of:

- Convenient online submission

- Thorough peer review

- No space constraints or color figure charges

- Immediate publication on acceptance

- Inclusion in PubMed, CAS, Scopus and Google Scholar

- Research which is freely available for redistribution

Submit your manuscript at www.biomedcentral.com/submit
C Biomed Central 